\title{
BIOTECNOLOGIA EM GENES HUMANOS: IMPLICAÇÕES NOS DIREITOS DE PROPRIEDADE INTELECTUAL EM SUA REGULAMENTAÇÃO INTERNACIONAL E BRASILEIRA
}

Tatyana Scheila Friedrich ${ }^{1}$

\section{RESUMO}

A manipulação de organismos vivos com o objetivo de se criar novos produtos que facilitem a vida humana, através do uso de técnicas científicas, engloba o amplo tema da biotecnologia. Dentro dessa amplitude, um dos aspectos que merecem a atenção dos estudiosos é o fato de que o resultado do trabalho de biotecnologia, em termos genéricos, pode ser patenteado quando resulta em invenção, o que pode gerar como conseqüência a concessão de direitos de propriedade intelectual sobre os seres vivos objetos de tais ações humanas. O presente trabalho aborda a regulamentação internacional e nacional desses direitos, enfocando, ao final, uma dos aspectos mais controversos do tema, ou seja, suas repercussões no campo da biotecnologia em genes humanos.

\section{DA BIOTECNOLOGIA EM GENES HUMANOS}

A biotecnologia engloba o conjunto de processos destinados a realizar a manipulação de organismos vivos, ou partes deles, através de técnicas específicas das ciências naturais e da engenharia, com o objetivo de obter produtos, serviços ou reações químicas que venham a facilitar a vida humana. As aplicações da biotecnologia se estendem a diversas áreas, tais como farmácia, medicina, agricultura, pecuária, meio ambiente, indústria bélica (armas biológicas).

As manipulações do genoma das espécies, com base na biologia molecular, são classificadas como "engenharia genética" e realizam-se,

\footnotetext{
${ }^{1}$ Doutora/UFPR e Professora de Direito Internacional Privado/UFPR
}

Revista Brasileira de Direito Internacional, Curitiba, v.4, n.4, jul./dez.2006 
principalmente, através de processos científicos voltados ao mapeamento, separação, duplicação, combinação e modificação dos genes.

\begin{abstract}
"Deve-se entender a biotecnologia, segundo alguns autores, como o conjunto de técnicas que permitem isolar células (animais ou vegetais, ou microorganismos), possibilitando sua utilização para obtenção de produtos ou para a catalisação de reações químicas. Se isso é dizer muito, não é dizer tudo. Podemos conceber a biotecnologia como toda a metodologia que utilize técnicas de manejo de organismos vivos ou algumas de suas partes, com a finalidade de obter bens e serviços que satisfaçam as mais diversas necessidades humanas."
\end{abstract}

A biologia molecular permite transferir moléculas biológicas do organismo que as criou para outros organismos porque parte do princípio da independência da molécula em relação ao organismo, tendo em vista que a atividade molecular se rege unicamente pela sua própria estrutura química, sem relação com o organismo a que está vinculada.

Quando a manipulação de material de células vivas é realizada com o objetivo de prevenir ou tratar doenças, dá-se o nome de terapia gênica. Atualmente a terapia gênica está limitada ao tratamento das células somáticas mas muito já se discute sobre as células da linha germinal, cuja modificação genética transmitir-se-á às gerações sucedâneas.

$\mathrm{Na}$ clonagem o núcleo da célula é colocado em meio citoplasmático diferente do seu original, portanto, não há manuseio no genoma através de modificação do núcleo celular:

"Se cada célula tem igual informação, ainda que se diferenciem
funcionalmente, toda e qualquer célula do organismo tem potencialmente
todas as informações necessárias para a construção de um organismo inteiro.
No entanto, para que o fenômeno possa evidenciar-se, é preciso retirar a
diferenciação, devendo permanecer, exclusivamente, aquelas informações
necessárias. O processo pode ser obtido colocando-se o núcleo de uma célula
somática já diferenciada no citoplasma do óvulo do qual se extraiu seu
núcleo. O óvulo, contendo um número normal de cromossomos, poderá ser
acionado, provocando-se sua divisão por partenogênese, ou seja, sem

${ }^{2}$ BURILLO, Isaias Zarazaga. Biotecnologia genética na agricultura e na pecuária (da produção à la carte às novas normas ético-jurídicas). CASABONA. Carlos Maria Romeo (org). Biotecnologia, Direito e Bioética. Perspectivas em Direito Comparado. Belo Horizonte: Del Rey e PUC Minas, 2002. p. 227.

Revista Brasileira de Direito Internacional, Curitiba, v.4, n.4, jul./dez.2006 
fecundação e reproduzirá no embrião toda a característica genérica do indivíduo ao qual pertence o núcleo transplantado ao óvulo."3

Devido à importância do tema e as repercussões para a vida humana, animal e vegetal do planeta, toda a discussão sobre a biotecnologia pressupõem a necessidade de regulamentação jurídica, de análise sob o ponto de vista ético e de debate com toda a população civil, não podendo limitar-se a alguns estudiosos dos países desenvolvidos.

\section{DA PROPRIEDADE INTELECTUAL}

A propriedade intelectual constitui-se no resultado de determinado trabalho inventivo que resulta em direitos específicos do seu criador. Os direitos de propriedade intelectual são concedidos sob a forma de um monopólio de exploração, ao longo de determinado lapso temporal, a partir de uma regulamentação especializada que exclui a possibilidade de terceiros fabricarem, utilizarem ou disporem da invenção. Difere, portanto, do mero descobrimento, fruto da observação do mundo fático.

A patente é um título de propriedade, conferido pelo Estado, em favor do titular - que pode ser pessoa física ou jurídica, pública ou privada, nacional ou transnacional - que desfruta do monopólio na exploração de processo ou de produto, por certo lapso temporal. No Brasil, esse prazo para as patentes de invenção é de vinte anos. ${ }^{4}$

Na seqüência, será abordada a regulamentação da matéria em âmbito internacional e no ordenamento jurídico brasileiro.

\subsection{DIREITO INTERNACIONAL}

O sistema internacional de propriedade intelectual é constituído por complexa estrutura de leis e costumes nacionais, além de tratados e práticas internacionais.

\footnotetext{
3 ALARCÓN, Pietro de Jesús Lora. Patrimônio Genético Humano e sua proteção na Constituição Federal de 1988. São Paulo Editora Método. 2004. p. 305.

${ }^{4}$ Ver PIMENTEL, Luiz Otávio e DEL NERO, Patrícia Aurélia, Propriedade Intelectual, in BARRAL, WELBER (Org.). O Brasil e a OMC. $2^{\mathrm{a}}$ ed. ver. E at. Curitiba: Juruá, 2002, p. 54.
}

Revista Brasileira de Direito Internacional, Curitiba, v.4, n.4, jul./dez.2006 
O primeiro tratado celebrado foi a Convenção da União de Paris (CUP), com o nome oficial de "Convenção da União de Paris para a Proteção da Propriedade Industrial", a qual foi aprovada e assinada em 1883, dando origem ao hoje denominado Sistema Internacional da Propriedade Industrial. Foi a primeira tentativa de uma harmonização internacional dos diferentes sistemas jurídicos nacionais relativos a propriedade industrial. Surge, assim, o vínculo entre uma nova classe de bens de natureza imaterial e a pessoa do autor, assimilado ao direito de propriedade.

Os trabalhos preparatórios dessa Convenção Internacional se iniciaram em Viena, no ano de 1873, e foram impulsionados em função de um caso concreto na área comercial. Ela teve seu início sob a forma de anteprojeto, redigido em uma Conferência Diplomática realizada em Paris no ano de 1880. Nova conferência foi convocada em 6 de março de 1883, para aprovação definitiva do texto, que entrou em vigor um mês depois do depósito de instrumentos de ratificação, em 7 de julho de $1883 .^{5}$

A Convenção não tenta uniformizar as leis nacionais - objetivo do futuro acordo TRIPS - nem condiciona o tratamento nacional à reciprocidade. Ao contrário, prevê ampla liberdade legislativa para cada país, exigindo apenas paridade: o tratamento dado ao nacional beneficiará também o estrangeiro. Isso significa que os países não eram obrigados a conceder patentes mas, caso o fizessem, deveriam dá-la ao nacional e ao estrangeiro. Contraditoriamente, vários países desenvolvidos utilizaram-se dessa prerrogativa da Convenção e abstiveram-se de conceder patentes enquanto países sem desenvolvimento industrial, como o Brasil, inverteram suas estatísticas e passaram a conceder um número muito maior de patentes a estrangeiros, se comparados com patentes nacionais.

Quanto às patentes, a Convenção prescreve ainda a independência de cada privilégio em relação aos outros, concedidos pelo mesmo invento em outras partes. Ela foi elaborada de modo a permitir razoável grau de flexibilidade às legislações nacionais, desde que fossem respeitados alguns

\footnotetext{
${ }^{5}$ Os EUA não participaram das conferências, alegando que não seriam coniventes com os países europeus que tinham o hábito de permitir que invenções norte-americanas fossem reproduzidas na Europa, onde as patentes estrangeiras não eram protegidas.
}

Revista Brasileira de Direito Internacional, Curitiba, v.4, n.4, jul./dez.2006 
princípios fundamentais, considerados de observância obrigatória pelos países signatários. Criou-se um "território da União", constituído pelos países contratantes, onde se aplicam os princípios gerais de proteção aos Direitos de Propriedade Industrial.

A Convenção de Paris, apesar de ser o mais importante instrumento internacional sobre propriedade industrial até o momento, não é o único ${ }^{6}$. 0 Brasil foi um dos 14 países signatários originais e atualmente há 166 Estados contratantes ${ }^{7}$.

Desde o começo, a Convenção previa, em seu art. 14, a celebração de conferências periódicas de revisão a fim de introduzir no texto original instrumentos destinados a aperfeiçoar o sistema da união à luz da experiência obtida em sua aplicação prática. Várias foram as modificações introduzidas no texto de 1883 através de 7 revisões. Na primeira, em Roma, os atos assinados não foram ratificados por nenhum país. Seguiram-se as Revisões de Bruxelas (1900), Washington (1911), Haia (1925), Londres (1934), Lisboa (1958) e Estocolmo (1967), sendo um novo processo de revisão iniciado em 1980, em Genebra.

A citada opção brasileira de conceder patentes, sobretudo aos pedidos estrangeiros, prevaleceu até a década de 60 e desestimulou o investimento em tecnologia local. A partir desse período, os países em desenvolvimento, liderados pelo Brasil, passaram a contestar a igualdade de tratamento da

\footnotetext{
${ }^{6}$ Ainda no âmbito da Convenção, há uma série de tratados restritos: o acordo de Madri, de 1891, que prevê o registro Internacional de Marcas; no mesmo ano, o acordo de Indicações de Procedência, ainda em vigor no Brasil na sua revisão de 1925; o acordo da Haia de Patentes de Desenho e Modelo Industrial; o acordo de Nice, de Classificação de Marcas; o acordo de Estrasburgo, de Classificação de Patentes; o Patent Cooperation Treaty de Washington, de 1970; o Tratado de Viena de Signos Tipográficos; e o Tratado de Praga para Depósito de Microorganismos. Fora da Convenção de Paris há outros tratados com características interessantes: o primeiro prevê o Registro de Descobertas Científicas, o segundo é a Convenção de 1961 sobre Proteção de Cultivares, ou Variedades de Plantas (UPOV); nota-se, ainda, o Tratado de Washington sobre Topografias de Circuitos Integrados, ainda não em vigor. O Brasil participa, ainda, de outros quatro tratados sobre propriedade industrial em vigor: dois acordos bilaterais (Panamá-Brasil e Uruguai-Brasil); Convenção Interamericana de 1911, de Buenos Aires, para Patentes de Desenhos e Modelos Industriais, e Convenção Interamericana de 1923, de Santiago do Chile, de Marcas e Nomes Industriais. O Brasil, país signatário original, aderiu à Revisão de Estocolmo em 1992. Disponível no sítio eletrônico do Instituto Nacional de Propriedade Intelectual, URL: http://www.inpi.gov.br, capturado em 22 de abril de 2004.

7 Disponível no sítio eletrônico da Organização Mundial da Propriedade Intelectual, URL: http://www.wipo.int, capturado em 25 de abril de 2004.
}

Revista Brasileira de Direito Internacional, Curitiba, v.4, n.4, jul./dez.2006 
Convenção de Paris em relação a todos os Países partes, exigindo alguns privilégios para si, já que se encontravam em situação desfavorável quanto aos aspectos industrial e econômico. $\mathrm{O}$ objetivo era permitir o desenvolvimento gradual desses países, de modo a facilitar seu acesso paulatino ao sistema de propriedade intelectual.

A luta dos países em desenvolvimento teve seu ápice na década de 80 , sobretudo na referida conferência diplomática de Genebra. No entanto, a posição contrária dos EUA conteve as mudanças desejadas, impediu qualquer forma alteração da Convenção para inclusão de um modelo de "desigualdade igualitária", conforme pode ser observado nas palavras de Denis Borges BARBOSA:

\footnotetext{
"Começou essa conferência diplomática em Genebra no ano de 1981. A situação política da convenção apresentava o seguinte quadro: certo número de países europeus estava favorável, ou moderadamente favorável a essa mudança; os Estados Unidos - isolados, na mesma posição em que estavam em 1883, num isolamento majestático - preferiam que a conferência diplomática não seguisse. E começaram a oferecer todo tipo de objeções. Não vou entrar no mérito desse episódio distante, só narrar o último momento, que dá um prognóstico do que será a propriedade intelectual nos anos a vir. Depois de várias manobras, conseguiu a delegação brasileira resolver o problema processual que empatou durante 30 dias o início da conferência. Votou-se, enfim, ao início da conferência, aplicando simplesmente o princípio da maioria. Iríamos mudar a Convenção de Paris por maioria e não por unanimidade. Esse é o ponto central. Votou-se essa proposta, que foi vencedora, democraticamente, por 113 a 1 . O voto isolado era, evidentemente, o americano. Vencedora a proposta, decide-se mudar o sistema de propriedade intelectual em todo o mundo por voto de maioria. $\mathrm{O}$ representante americano ergue-se e diz: "Está tudo muito bom, está tudo muito bem, vocês estão falando em interesses dos países em desenvolvimento, em transferência de tecnologia, em eqüidade econômica, mas o que me interessa é o interesse das minhas empresas. Aqui não estamos falando de cooperação entre pessoas, estamos falando de interesse entre empresas. E assim é que essa conferência não vai continuar". E assim, pelo voto de um contra 113 , a conferência nunca continuou."
}

Nas últimas décadas do século $\mathrm{XX}$, o destaque dado pela política comercial à proteção da propriedade intelectual como núcleo do desenvolvimento econômico foi decorrente do processo de globalização da

\footnotetext{
${ }^{8}$ BARBOSA, Denis Borges. Propriedade intelectual: da Convenção de Paris ao patamar do novo milênio. Palestra. Workshop Políticas de propriedade intelectual, negociação, cooperação e comercialização de tecnologia em universidades e instituições de pesquisa: análise e proposições. Rio de Janeiro: Rede de Tecnologia do Rio de Janeiro, Brasília: ABIPTI, 1998. p. 23-24.
}

Revista Brasileira de Direito Internacional, Curitiba, v.4, n.4, jul./dez.2006 
própria economia e dos avanços tecnológicos. A produção industrial foi se modificando para setores vinculados à pesquisa e criatividade, tornando-as uma filosofia empresarial e um fator determinante de êxito na competição mundial. Como conseqüência, a circulação de mercadoria propiciou a pirataria, aumentando as tensões entre os países industrializados e os emergentes, onde o sistema de propriedade intelectual era menos desenvolvido ou mesmo inexistente, posto que os direitos de propriedade intelectual eram um elemento de competitividade. Revelou-se a íntima relação entre o comércio internacional e os direitos de propriedade intelectual, transferindo-se as deliberações sobre esta última do âmbito da Organização Mundial de Propriedade Intelectual (OMPI) para o Acordo Geral sobre Tarifas e Comércio (GATT). Era necessária uma adequada e eficaz proteção jurídica, o que fez surgir o Acordo sobre Aspectos dos Direitos de Propriedade Intelectual relacionados ao Comércio (TRIPS).

O Acordo TRIPS representa uma tentativa de regular e proteger diferentes bens imateriais no mundo. É um acordo complexo, não apenas pelo seu conteúdo substantivo e adjetivo, mas pelo enfoque dado ao tema, vinculando-o à vida econômica e comercial. Representa uma mudança nos institutos da propriedade intelectual, dando lhe outra interpretação. O Acordo possui dois mecanismos básicos contra as infrações à propriedade intelectual: a elevação do nível de proteção em todos os Estados membros e a garantia da observação dos direitos de propriedade intelectual. Além disso, estabelece princípios básicos, quanto à existência, abrangência e exercício dos direitos de propriedade intelectual.

O Acordo TRIPS, adotado por ocasião da Rodada Uruguai do GATT, em 1994, quando foi criada a OMC, estabelece os padrões universais mínimos sobre direitos autorais e direitos conexos, marcas, indicações geográficas, desenhos industriais, patentes, topografias de circuitos integrados, proteção de informação confidencial (segredos de comércio), controle de práticas de concorrência desleal em contratos de licenças, bem como prevê cláusulas sobre procedimentos judiciais e administrativos e outras medidas relativas ao reforço dos direitos. O objetivo implícito do Acordo TRIPS é uniformizar as 
normas referentes à propriedade intelectual, de sorte que, ao fixar princípios e regras gerais, os Estados Membros da OMC deverão adequar suas normas domésticas.

A negociação do Acordo TRIPS visou complementar convenções internacionais existentes sobre a propriedade intelectual, incluindo a Convenção de Paris para a Proteção da Propriedade Intelectual. As definições sobre propriedade intelectual no mundo, acordadas na Convenção de Paris, são ainda base e fundamento para toda e qualquer nova norma a ser aprovada, seja nas relações de comércio como no Acordo TRIPS, seja nas relações envolvendo o mundo virtual, como no conflito entre marcas famosas e nomes de domínio na internet. Entretanto, muito embora o Acordo TRIPS harmonize parte das normas relativas aos direitos de propriedade intelectual relacionados ao comércio, deixa ampla margem de liberdade aos Estados para legislar sobre o tema. Os países em desenvolvimento estão cumprindo plenamente as disposições do acordo desde o dia $1^{\circ}$ de janeiro de $2000^{9}$. No Brasil, a Ata Final da Rodada Uruguai, que institucionalizou a OMC, e demais acordos conexos, entre eles o TRIPS, foram incorporados ao ordenamento jurídico interno pelo Decreto 1355, de 30/12/1994.

A inclusão do TRIPS nos acordos multilaterais da OMC foi possível devido à pressão exercida pelos países desenvolvidos sobre os países em desenvolvimento, que esperavam em troca obter ganhos com a liberalização do comércio de têxteis e vestuário. Mais tarde estes perceberam que os ganhos foram insuficientes e que o TRIPS não só incorporaria uma forma de patenteamento favorável aos países desenvolvidos como também interferiria drasticamente em seus esforços para prover tratamento de saúde à população de baixa renda para várias doenças, e especialmente a AIDS. Conseqüentemente, procurou-se revisar o TRIPS em reuniões subseqüentes, sobretudo por ocasião da Quarta Conferência Ministerial da OMC, que teve lugar na cidade de Doha, no Qatar, de 11 a 14 de novembro de 2001, e que foi concluída com uma "Declaração sobre o TRIPS e a saúde pública".

\footnotetext{
${ }^{9}$ Acordo TRIPS, artigo 65, § 1 e 2.
}

Revista Brasileira de Direito Internacional, Curitiba, v.4, n.4, jul./dez.2006 
As críticas ao modelo TRIPS concentram-se nos argumentos de que ele é um acordo formado a partir de uma concepção capitalista e ocidental das noções de conhecimento, descoberta, exploração, inovação e riqueza.

\begin{abstract}
"Segundo o Artigo 27.1, para ser patenteável, uma inovação deve ter potencialmente uma aplicação industrial. Isto imediatamente exclui todos os setores que produzem e inovam fora do modo de organização industrial. $\mathrm{O}$ lucro e a acumulação de capital são os únicos fins da criatividade; o bem social não é mais reconhecido. Sob o controle das corporações, ocorre a desindustrialização das produções em pequena escala nos setores informais da sociedade". ${ }^{10}$
\end{abstract}

Alega-se que os direitos de propriedade intelectual (DPI), tal como concebidos pelo Acordo TRIPS, excluem os conhecimentos coletivos, comuns em comunidades camponesas e indígenas, onde são repassados de geração para geração.

\footnotetext{
"Conforme declara o preâmbulo do acordo, os DPI são reconhecidos apenas como direitos privados. Isso exclui todos os tipos de conhecimento, idéias e inovações que acontecem nas "terras comunitárias intelectuais" - nos povos entre os lavradores, nas florestas entre os povos tribais, e até mesmo nas universidades entre os cientistas. $\mathrm{O}$ acordo sobre os TRIPS é, portanto, um mecanismo para a privatização das "terras comunitárias intelectuais" e a desintelectualização da sociedade civil. A mente se torna um monopólio das grandes empresas." $" 11$
}

Os países em desenvolvimento denunciam ainda a tendência, em parte causada pelo modelo TRIPS, de supressão da diversidade local por variedades patenteadas; de transformações na convivência ecológica de organismos patenteados e geneticamente modificados, afetando a biodiversidade e criando novas formas de poluição; de controle de mercado pelo seleto grupo de indústrias beneficiadas pelo Acordo TRIPS, dificultando novas invenções criadas por novas indústrias.

Um dos pontos mais difíceis da negociação do Acordo TRIPS foi o tema da proteção de patentes para remédios, já que perto de cinqüenta países não conferiam esse tipo de proteção. A proteção de invenções biotecnológicas

\footnotetext{
${ }^{10}$ SHIVA, Vandana. Biopirataria: a pilhagem da natureza e do conhecimento. Tradução Laura Cardellini Barbosa de Oliveira. Petrópolis: Vozes, 2001. p.32.

${ }^{11}$ SHIVA, Vandana. Biopirataria: a pilhagem da natureza e do conhecimento. Tradução Laura Cardellini Barbosa de Oliveira. Petrópolis: Vozes, 2001. p.32.
}

Revista Brasileira de Direito Internacional, Curitiba, v.4, n.4, jul./dez.2006 
também constituía um problema, em razão da crescente importância da aplicação da engenharia genética em diferentes campos, como o farmacêutico, de diagnósticos e desenvolvimento de sementes ${ }^{12}$.

O parágrafo primeiro do artigo 27 estabelece a regra geral sobre patentes $^{13}$ e representa uma das maiores concessões feitas pelos países em desenvolvimento nas negociações do TRIPS, dado que a exclusão das patentes era permitida para vários produtos e processos, e notadamente farmacêuticos e alimentos, em muitos países na época em que a Rodada Uruguai era proposta ${ }^{14}$

Já os parágrafos 2 e 3 do Artigo 27 trazem as exclusões para a patenteabilidade que as legislações nacionais estão autorizadas a estabelecer. O Artigo $27 \S 2$ prevê a exceção com a finalidade de proteger a ordem pública e a moralidade. É o alento para os países em desenvolvimento que encontram nesse dispositivo o único instrumento para a resistência ao modelo de patentes. No campo das regras multilaterais relativas à propriedade intelectual enquanto temática comercial, a biotecnologia tem a seguinte disciplina jurídica, prevista no Artigo 27 3: "Os Membros também podem considerar como não patenteáveis: (a) métodos diagnósticos, terapêuticos e cirúrgicos para 0 tratamento de seres humanos ou de animais; (b) plantas e animais, exceto microorganismos e processos essencialmente biológicos para a produção de plantas ou animais, excetuando-se os processos não-biológicos e microbiológicos. Não obstante, os Membros concederão proteção a variedades vegetais, seja por meio de patentes, seja por meio de um sistema sui generis eficaz, seja por uma combinação de ambos. O disposto neste subparágrafo

\footnotetext{
${ }^{12}$ CORREA, Carlos M. "Acordo TRIPS: Quanta flexibilidade há para implementar os direitos de patente?", in DAL RI JUNIOR, Arno e OLIVEIRA, Odete Maria (Org.). Direito Internacional Econômico em Expansão. Desafios e Dilemas. ljuí: Editora Unijuí, 2003, p. 363.

${ }_{13}$ Artigo 27.1 "Sem prejuízo do disposto nos parágrafos 2 e 3 abaixo, qualquer invenção, de produto ou de processo, em todos os setores tecnológicos, será patenteável, desde que seja nova, envolva um passo inventivo e seja passível de aplicação industrial. Sem prejuízo do disposto no parágrafo 4 do Artigo 65, no parágrafo 8 do Artigo 70 e no parágrafo 3 deste Artigo, as patentes serão disponíveis e os direitos patentários serão usufruíveis sem discriminação quanto ao local de invenção, quanto a seu setor tecnológico e quanto ao fato de os bens serem importados ou produzidos localmente".

${ }^{14}$ CORREA, Carlos M. "Acordo TRIPS: Quanta flexibilidade há para implementar os direitos de patente?", in DAL RI JUNIOR, Arno e OLIVEIRA, Odete Maria (Org.). Direito Internacional Econômico em Expansão. Desafios e Dilemas. ljuí: Editora Unijuí, 2003, ps. 361-424, p. 364.
}

Revista Brasileira de Direito Internacional, Curitiba, v.4, n.4, jul./dez.2006 
será revisto quatro anos após a entrada em vigor do Acordo Constitutivo da OMC".

A Declaração de Doha confirmou a existência de "flexibilidades" no TRIPS e, particularmente, em relação à aplicação de dispositivos em licenças compulsórias e depauperamento de direitos ("importações paralelas”). Embora a Declaração trate de problemas de saúde pública e tenha sido adotada para dar uma resposta aos países em desenvolvimento em relação à matéria, seu conceito básico - a flexibilidade em acomodar-se a diferentes leis nacionais se aplica a todas as áreas reguladas pelo Acordo. O principal campo de controvérsia no contexto Norte-Sul está na interpretação das principais cláusulas do TRIPS relacionadas à lei de patentes.

Conforme visto, o sistema de patentes traduz-se no direito de o inventor apropriar-se com exclusividade do bem intangível resultante de sua criação; da mesma forma como é reconhecido o direito exclusivo de propriedade de um bem tangível ou material. Como o controle do uso da invenção pelo detentor da patente deriva do direito de excluir outros de usar a invenção, a patente estabelece um poder de monopólio, por um período determinado, para o seu detentor. Assim, a patente, a partir de sua própria concepção, envolveria uma inconsistência ideológica já que sociedades que favorecem a livre iniciativa através da competição, encorajam monopólios sob a forma de patente. Esse é um dos pontos de partida para o debate entre os países desenvolvidos e os países em desenvolvimento ${ }^{15}$.

Os países desenvolvidos consideram a patente como o melhor meio de remunerar o investimento privado, ao passo que os países em desenvolvimento tendem a considerar que o monopólio resultante da patente pode ser utilizado para a obtenção de lucros desproporcionais, em prejuízo do direito da sociedade de usufruir novas tecnologias a baixo custo. $O$ conflito entre o interesse da sociedade e o interesse privado do detentor da patente é, pois, uma das principais razões pelas quais alguns países em desenvolvimento hesitam em implementar sistemas de proteção de patentes rígidos. Ademais, alguns países em desenvolvimento, como Brasil e Índia, consideram que a

${ }^{15}$ POMPEU BRASIL FROTA, Maria Stela. Proteção de Patentes de Produtos Farmacêuticos: 0 Caso Brasileiro. Brasília: FUNAG/IPRI, 1993, p. 55.

Revista Brasileira de Direito Internacional, Curitiba, v.4, n.4, jul./dez.2006 
propriedade intelectual, e a patente em particular, devem ser utilizadas como instrumento de política de desenvolvimento, e, portanto, adaptadas às necessidades de cada país, daí a exclusão de determinados setores, como o de medicamentos, do direito de proteção. Os países desenvolvidos, por sua vez, vêem-na como uma proteção a ser aplicada de maneira uniforme em todo o mundo ${ }^{16}$.

Dentre os riscos do sistema de patentes destaca-se a geração de abusos monopolísticos, quando o objetivo social da divulgação de uma nova tecnologia não é alcançado. Isso ocorre, por exemplo, quando o detentor da patente decide não aplicar sua descoberta na fabricação do novo produto durante o período em que detém o monopólio de seu uso, ou prolonga seu monopólio por meio de patenteamento sucessivo de melhoramentos estratégicos da invenção ou por meio da criação de mercado cativo para uma determinada marca estabelecida durante o período de duração da patente. Também a exploração insuficiente de uma invenção pode constituir-se em abuso de monopólio, porque a produção abaixo das necessidades de consumo da população pode levar a um preço excessivo do produto. Esse tipo de abuso, no entanto, é considerado por alguns especialistas como um dos custos inerentes ao sistema de patentes, uma vez que pertence à essência mesma da patente a faculdade de restringir a competição, durante um período, e de permitir que o detentor da patente possa administrar seu preço. Dentre as formas encontradas para neutralizar esses abusos destaca-se o licenciamento compulsório, que autoriza uma terceira pessoa, sob determinadas condições, a explorar a invenção patenteada ${ }^{17}$. Esse foi o objeto da "Declaração de Doha sobre o Acordo TRIPS e a Saúde Pública". ${ }^{18}$

\footnotetext{
${ }^{16}$ POMPEU BRASIL FROTA, Maria Stela. Proteção de Patentes de Produtos Farmacêuticos: 0 Caso Brasileiro. Brasília: FUNAG/IPRI, 1993, p. 55-56.

${ }^{17}$ POMPEU BRASIL FROTA, Maria Stela. Proteção de Patentes de Produtos Farmacêuticos: 0 Caso Brasileiro. Brasília: FUNAG/IPRI, 1993, p. 56-57.

${ }^{18}$ Não há dúvidas de que o texto final da Declaração foi o mais dúbio, e não o melhor. Devendo contemplar as expectativas de todos, inclusive as dos mais fracos, o consenso carrega consigo a ambigüidade e a contradição. A proposta apresentada na Conferência de Doha por Brasil e Índia, com o apoio de outros cinqüenta países em desenvolvimento, antepunha as políticas públicas de saúde ao TRIPS, que protege as patentes de remédios. A oposição veio dos Estados Unidos com o suporte da Suíça, outro país que abriga empresas transnacionais de medicamentos. Algumas organizações não governamentais chegaram a mencionar que se iniciava um "combate entre os lucros e a vida". O texto final da Declaração dispõe que "o
}

Revista Brasileira de Direito Internacional, Curitiba, v.4, n.4, jul./dez.2006 
A Declaração de Doha representou um importante avanço para a humanização do Acordo TRIPS. Apesar de direcionada à questão dos medicamentos, tornou-se um modelo também para outros temas, como o da proteção da biodiversidade do planeta. Tem relevância para a biotecnologia porque colocou a função social da propriedade intelectual acima dos interesses comerciais, resgatando a responsabilidade universal e o compromisso com a solidariedade e os direitos humanos. O desafio, agora, é implementá-la.

\subsection{DIREITO BRASILEIRO}

No que diz respeito ao tema da propriedade intelectual, historicamente, o Brasil tem se adaptado prontamente aos ditames internacionais, não tendo sido diferente em relação aos tratados celebrados no âmbito da OMC.

\footnotetext{
"No contexto de suas obrigações com a OMC, o Brasil concluiu, desde 1995, quando foi a adesão brasileira ao acordo constitutivo da OMC, a revisão do arcabouço jurídico relativo à propriedade intelectual. Tivemos a Lei de Propriedade Industrial em 96, a de cultivares em 97, a de direitos autorais e softwares em 98 e, estamos com o projeto de circuito integrado em tramitação",19
}

Quanto ao Acordo TRIPS, especificamente, o Brasil adequou seu direito interno por meio da Lei 9279, de 14 de maio de 1996: Lei de Propriedade Industrial,

acordo Trips não impede e não deveria impedir os membros de tomar medidas para proteger a saúde pública. Em conseqüência, enquanto reiteramos nosso compromisso com o acordo Trips, nós afirmamos que o acordo deveria ser interpretado e implementado de maneira consentânea com o direito dos membros da OMC de proteger a saúde pública e, em particular, de assegurar remédios para todos". Assim, a Declaração reafirmou o direito dos Membros da OMC à aplicação dos dispositivos do TRIPS, mas afirmou também que este deveria ser interpretado de forma a permitir a proteção da saúde pública, o que incluiria o direito à garantia de licenças compulsórias para facilitar o tratamento de doenças como a AIDS, a tuberculose e a malária. Infelizmente, após cinco reuniões formais do Conselho formado por representantes de vários países, não foi possível tirar a Declaração de Doha do papel. Um consenso não pôde ser alcançado porque a Delegação dos Estados Unidos queria limitar o alcance da Declaração à malária, tuberculose e AIDS, aceitando, no máximo, a criação de uma lista limitada de doenças infecciosas. Frente ao impasse quanto ao alcance das doenças cobertas, que interfere diretamente na liberdade de vários países para produzir e comercializar a preços mais baratos medicamentos patenteados, a OMS entende que se está hoje distante de uma solução prática e factível para o problema. Assim, o tema foi inserido nas pautas das Conferências Ministeriais da OMC que se seguem.

${ }^{19}$ PINHO, Jane. Planejamento Estratégico da Propriedade Intelectual: 1998-2000. Workshop Políticas de propriedade intelectual, negociação, cooperação e comercialização de tecnologia em universidades e instituições de pesquisa: análise e proposições. Rio de Janeiro: Rede de Tecnologia do Rio de Janeiro, Brasília ABIPTI, 1998. p. 41.

Revista Brasileira de Direito Internacional, Curitiba, v.4, n.4, jul./dez.2006 
conhecida como Lei de Patentes. Proposta pelo Executivo em 1992 e aprovada pelo Congresso Nacional após quatro anos de intensos debates, a Lei de Propriedade Industrial o reflete os inúmeros lobbies e pressões sofridos pelo governo e parlamentares brasileiros durante sua tramitação.

\footnotetext{
"O Brasil sofreu fortes pressões internacionais, notadamente dos Estados Unidos, por parte das indústrias químicas, farmacêuticas e de informática. Teve que se sujeitar a retaliações e sanções comerciais, com grande prejuízo à nossa economia. Figurou, inclusive, na lista dos países em observação. $\mathrm{O}$ interesse internacional era que o Brasil aprovasse uma nova lei de propriedade industrial, onde privilegiasse as fórmulas bioquímicas e protegesse os direitos autorais no setor de informática."20
}

A demora na aprovação da referida lei deveu-se à mobilização da sociedade civil brasileira que, dentre outras frentes de trabalho, criou o Fórum para a Liberdade do Uso do Conhecimento. Formado por aproximadamente 300 entidades, como universidades, associações de classe, de empregados e empregadores de indústrias nacionais, o Fórum realizou inúmeras atividades para fazer a pressão inversa, criando centros de divulgação e discussão sobre os impactos negativos que seriam gerados pela aprovação da lei.

Bautista VIDAL posicionou-se de forma contrária à Lei de Patentes desde sua gênese, alegando ser lesiva aos interesses nacionais. Pode-se resumir seus argumentos nas seguintes ponderações, ainda a respeito do projeto de lei que lhe deu origem:

- Concentração dos dispositivos na questão dos benefícios dos detentores dos privilégios;

- Eliminação quase completa da figura original do inventor ou de qualquer direito do pesquisador-empregado a vantagens sobre 0 invento patenteado, privilegiando as empresas empregadoras;

- Generalização do monopólio das patentes a todos os setores produtivos;

${ }^{20}$ CHINEN, Akira. Know-how e propriedade industrial. São Paulo. Editora Oliveira Mendes, 1997. p.3

Revista Brasileira de Direito Internacional, Curitiba, v.4, n.4, jul./dez.2006 
- Diminuição dos instrumentos de proteção da sociedade e das empresas não-beneficiadas pelo monopólio;

- Concessão de privilégios a estrangeiros com efeitos legais retroativos-pipelines;

- Concessão de patentes a "microorganismos engenheirados", desrespeitando o princípio secular de somente se conceder patentes a invenções novas, de utilidade produtiva, tendo em vista que os microorganismos não são objeto de invenção e sim de descoberta na natureza;

- Impedimento de perspectiva de evolução tecnológica nacional ao provocar o congelamento sobre determinado espaço produtivo com a proteção não justificada de invento patenteado, ao reservar-lhe o mercado, em regime de monopólio, por longo período de 20 anos impedindo o avanço e o progresso;

- Concentração na idéia de intervenção estatal através da concessão de subsídios e privilégios, que vão gerar monopólios em benefício de interesses estrangeiros. ${ }^{21}$

Apesar de ser considerada por setores da sociedade civil do Brasil como uma lei em benefício do capital estrangeiro, o governo norte-americano não se considerou plenamente satisfeito e passou a denunciar que a Lei brasileira de patentes estabelece a discriminação entre a patente estrangeira e a nacional, além de alegar que a exigência da produção nacional é contrária ao TRIPS.

Conforme analisado anteriormente, o impasse com os EUA se consolidou quando o Brasil passou a defender internacionalmente a tese do abuso de direito e do poder econômico para recorrer à licença compulsória, a fim de quebrar as patentes e

\footnotetext{
${ }^{21}$ VIDAL, J. W Bautista. O Esfacelamento da Nação. Petrópolis: Vozes, 1994. passim (ver especialmente capítulo III Lei de Patentes: A chantagem do século). "Pelas circunstâncias práticas de nossa realidade atual, após longo período de recessão e de políticas econômicas que a promovem, as patentes privilegiam um restrito clube, do qual estão excluídas as empresas de capital nacional. Trata-se de modo de enérgica intervenção do Estado que objetiva entregar setores inteiros de nossa economia ao controle externo, especialmente aqueles que envolvem a segurança de vida dos cidadãos,como o farmacêutico e alimentar; ademais, pelo patenteamento de microorganismos, essa entrega estender-se-á a setores potencialmente estratégicos de peso mundial, como o energético da biomassa,único caminho universal para a substituição do petróleo, em exaustão no planeta, e dezenas de outros". VIDAL, J. W Bautista. Monopólio das Patentes. Revista Adusp, maio 1996. p.32.
}

Revista Brasileira de Direito Internacional, Curitiba, v.4, n.4, jul./dez.2006 
garantir a produção local de medicamentos anti-retrovirais, considerados excessivamente custosos pelo governo brasileiro. Os EUA recorreram à OMC mas acabaram retirando a queixa. O Brasil mantém sua proposta original: realização de acordo de preços diferenciados para os remédios, interpretação flexibilizada do TRIPS, acesso universal, criação de um fundo internacional para atender às populações pobres, manutenção de sua legislação interna.

Em realidade, a Lei 9279 privilegia a fabricação no país do objeto da proteção patentária, tendo em vista que o objetivo dessa política governamental é promover a geração de empregos e riquezas no território brasileiro, e que a proteção intelectual deve estar alicerçada em um esforço mais amplo de estímulo à pesquisa e à inovação tecnológica no país, além da busca de capacitação para geração de produtos e processos tecnologicamente mais avançados em todas as áreas do conhecimento.

Conceitualmente, a patente não é direito absoluto, ao contrário, desde sua origem obedece a limitações e condições: territorialidade, prazo de vigência, novidade, atividade inventiva, aplicação industrial, possibilidade de salvaguardas para equilibrar direitos e obrigações e, no caso do Brasil, do mandamento constitucional de subordinação da propriedade, inclusive a intelectual, à sua função social.

No entanto, as regras de livre comércio, em especial aquelas do Acordo TRIPS, impõem limites a essa política nacional, seja porque a produção local pode ser insuficiente para atender à demanda, caracterizando sua inviabilidade econômica, seja porque a fabricação local pode representar perda de qualidade, aumento de custo e preço ou transferência de subsídios ao fabricante.

Assim, a possibilidade de que a Lei de Propriedade Industrial efetivamente contribua para a formulação e a execução de políticas, como instrumento para indução de investimentos e empregos, diz particularmente respeito ao tratamento dispensado a três matérias: a exploração local do objeto da patente (fabricação local versus importação irrestrita), a importação paralela (importação direta pelo titular ou licenciado versus importação por terceiros) e a licença compulsória para o titular da patente que não estiver explorando seu objeto no território nacional. 
O artigo $68^{22}$ da Lei é fruto de complexa engenharia política e jurídica, decorrente de ampla e prolongada negociação no seio do Executivo e no Congresso Nacional. A solução adotada por esse dispositivo é intermediária e associa as questões da fabricação local, importação paralela e licença compulsória.

No início da tramitação da Lei de Propriedade Industrial, o Executivo pretendia privilegiar a fabricação local e, ao mesmo tempo, permitir a importação paralela do objeto da patente (a chamada exaustão internacional de direitos). Com o aprofundamento dos debates no Congresso Nacional, percebeu-se o conflito entre os dois mecanismos e houve uma mudança de posição no sentido de adotar-se a exaustão nacional, sabidamente de difícil defesa no contexto internacional. Considerou-se, à época, os possíveis conflitos que adviriam no plano internacional, dado o potencial de interpretações divergentes face à dimensão dos interesses econômicos em jogo, tendo-se concluído que a engenharia do artigo 68 , conjugado com os artigos 42, 43 e 74, seria defensável face aos acordos internacionais, inclusive o Acordo TRIPS, entre outros. As razões que fundamentaram essa conclusão são as seguintes:

A exploração local do objeto da patente é uma exigência absoluta do artigo $5^{\circ}$ da Convenção de Paris e, segundo a tradição predominante dos intérpretes daquela Convenção e o interesse dos países em desenvolvimento,

\footnotetext{
${ }^{22}$ Seção III, Da Licença Compulsória, Art. 68. "O titular ficará sujeito a ter a patente licenciada compulsoriamente se exercer os direitos dela decorrentes de forma abusiva, ou por meio dela praticar abuso de poder econômico, comprovado nos termos da lei, por decisão administrativa ou judicial. § $1^{\circ}$ Ensejam, igualmente, licença compulsória: I - a não exploração do objeto da patente no território brasileiro por falta de fabricação ou fabricação incompleta do produto, ou, ainda, a falta de uso integral do processo patenteado, ressalvados os casos de inviabilidade econômica, quando será admitida a importação; ou II - a comercialização que não satisfizer às necessidades do mercado. § ํㅡ A licença só poderá ser requerida por pessoa com legítimo interesse e que tenha capacidade técnica e econômica para realizar a exploração eficiente do objeto da patente, que deverá destinar-se, predominantemente, ao mercado interno, extinguindo-se nesse caso a excepcionalidade prevista no inciso I do parágrafo anterior. § $3^{\circ}$ No caso de a licença compulsória ser concedida em razão de abuso de poder econômico, ao licenciado, que propõe fabricação local, será garantido um prazo, limitado ao estabelecido no art. 74, para proceder à importação do objeto da licença, desde que tenha sido colocado no mercado diretamente pelo titular ou com o seu consentimento. $\S 4^{\circ}$ No caso de importação para exploração de patente e no caso da importação prevista no parágrafo anterior, será igualmente admitida a importação por terceiros de produto fabricado de acordo com patente de processo ou de produto, desde que tenha sido colocado no mercado diretamente pelo titular ou com o seu consentimento. $\S 5^{\circ}$ A licença compulsória de que trata $\circ \S 1^{\circ}$ somente será requerida após decorridos 3 (três) anos da concessão da patente.
}

Revista Brasileira de Direito Internacional, Curitiba, v.4, n.4, jul./dez.2006 
explorar localmente significa fabricar. $\mathrm{Na}$ inteligência do artigo $5^{\circ}$, a mera importação pode gerar licença compulsória, nos seguintes termos: "cada um dos países contratantes terá a faculdade de adotar medidas legislativas prevendo a concessão de licenças obrigatórias para prevenir abusos que poderiam resultar do exercício do direito exclusivo conferido pela patente como, por exemplo, a falta de exploração". A falta de exploração sem razões legítimas configura abuso. Por outro lado, a revisão de Estocolmo da Convenção de Paris concluiu que "a caducidade da patente só poderá ser prevista nos casos em que a concessão da licença obrigatória não tenha sido suficiente para prevenir tais abusos". Conforme a interpretação a contrario senso, nos termos do princípio inclusio unius exclusio alterius, a exploração por importação, quer dizer, a falta de fabricação local, não pode ser considerada como causa de caducidade. Portanto, pode ensejar licença compulsória.

A exploração do mercado brasileiro por meio exclusivamente da importação, ao reduzir a industrialização local, inibe alguns dos preceitos do TRIPS mais caros aos países em desenvolvimento, quais sejam: artigo 7 (Objetivos) -“A proteção e a aplicação de normas de proteção dos direitos de propriedade intelectual devem contribuir para a promoção da inovação tecnológica e para a transferência e difusão de tecnologia, em benefício mútuo de produtores e usuários de conhecimento tecnológico e de uma forma conducente ao bem-estar social e econômico e ao equilíbrio entre direitos e obrigações”; e artigo 8.2 (Princípios) -“Desde que compatíveis com o disposto neste Acordo, poderão ser necessárias medidas apropriadas para evitar 0 abuso dos direitos de propriedade intelectual por seus titulares ou para evitar o recurso a práticas que limitem de maneira injustificável o comércio ou que afetem adversamente a transferência internacional de tecnologia”.

As prescrições de TRIPS foram plenamente incorporadas na Lei 9.279/96, sendo, todavia, descabível a expectativa de aplicação direta do TRIPS no sistema jurídico brasileiro, já que o TRIPS determina que os Estados legislem livremente, respeitando certos padrões mínimos. A construção do artigo 68 da Lei 9.279/96 observou fielmente as disposições da Convenção de Paris e do TRIPS, em consonância com as expectativas das políticas industrial 
e de ciência e tecnologia do país. Sua inobservância constitui abuso penalizado por meio da licença compulsória.

O artigo 27 do TRIPS não proíbe a licença compulsória, mas a discriminação quanto ao fato de os bens serem importados ou produzidos localmente. Tampouco o artigo 31 veda a concessão de licenças compulsórias em razão de não uso da patente. Por força da Convenção de Paris, não existe discriminação quando a lei de um país dá idêntico tratamento ao seu nacional e a um estrangeiro, beneficiário da Convenção. $O$ que nunca foi considerado discriminatório por este diploma não passará a sê-lo sob o TRIPS.

Por outro lado, o artigo 6 do TRIPS dispõe que "Para os propósitos de solução de controvérsias no marco deste Acordo, e sem prejuízo do disposto nos artigos 3 e 4 (tratamento nacional e tratamento de nação mais favorecida), nada neste Acordo será utilizado para tratar da questão da exaustão dos direitos de propriedade intelectual'.

A Lei de Propriedade Industrial brasileira associa de forma inédita os três mecanismos - fabricação local, licença compulsória e importação paralela, privilegiando a fabricação local da patente sempre que economicamente viável sua produção em território nacional, em face do mercado brasileiro, facultando alternativamente a importação não exclusiva do titular e evitando, assim, a criação de reserva de mercado ou monopólio de importação.

A importação do objeto da patente somente ocorrerá caso se verifique a inviabilidade econômica de sua fabricação no Brasil (artigo 68, § 1ํ, I), porém, tal autorização estende-se não apenas ao titular da patente, mas também aos seus concorrentes. Desde que o titular esteja importando em decorrência de inviabilidade econômica, qualquer empresa também poderá importar o objeto da patente. Assim, o mérito do artigo 68 não é propriamente exigir a fabricação local, mas impedir que haja monopólio de importação - a importação incide como sanção para quem injustificadamente não fabrica no Brasil.

Assim, incide a licença compulsória em quaisquer das condições previstas no artigo 68, ou seja, caso se verifique abuso de direito ou de poder econômico; a não exploração do objeto da patente no território brasileiro por 
falta de fabricação ou fabricação incompleta do produto, ou, ainda, a falta de uso integral do processo patenteado; ou quando a comercialização não satisfizer às necessidades do mercado. Ficam ressalvados os casos de inviabilidade econômica, quando será admitida a importação - e, nesse caso, será igualmente admitida a importação por terceiros.

A licença compulsória foi criada para evitar abusos no exercício do direito de exploração exclusiva da patente e sua concessão limita-se aos casos de insuficiência de exploração; dependência de patentes; exercício abusivo; abuso de poder econômico; interesse público ou situação de emergência nacional. Segundo a lei, a capacidade técnica e econômica para a realização eficiente do objeto da patente e o legítimo interesse do requerente são indispensáveis para seu requerimento, que só pode ocorrer depois de 3 anos da concessão da patente. A licença poderá ser declarada caduca, gerando a perda do direito e o domínio público da patente se, depois de 2 anos, tal licença não se revelar suficiente para prevenir ou sanar os abusos ou desuso, salvo motivo justificado.

O artigo 68, conjugado com os artigos 42,43 e 74, afasta a concessão da licença compulsória para terceiros se o titular da patente estiver explorando regularmente o objeto protegido, demonstrando a viabilidade econômica da fabricação no país. O sentido desse dispositivo é sujeitar o titular à sanção - o que, de fato, caracteriza a licença compulsória - apenas na ocorrência de abuso de poder econômico.

A falta de fabricação pelo titular fundamentada em inviabilidade da escala de produção não configura um abuso passível dessa penalidade e, visando garantir o atendimento do mercado brasileiro nas condições de qualidade e preço do mercado internacional, é facultada a importação do produto, não apenas ao titular, mas também a terceiros - a chamada importação paralela.

Privilegia-se, assim, a fabricação local, sem, no entanto, impedir a importação do produto patenteado pelo titular ou por terceiros caso a produção local se mostre economicamente inviável em termos de economia de escala. Além desse caso, a Lei de Propriedade Industrial admite a concessão de 
licenças compulsórias para que terceiros possam explorar a patente nos casos já citados, como por exemplo, de emergência nacional, interesse público, abuso de direito ou de poder econômico pelo titular da patente, nos limites fixados pelo Acordo TRIPS.

Cabe lembrar a regra básica da exaustão internacional (uma vez colocado o produto no mercado pelo titular da patente ou seu licenciado, ele não pode impedir a livre circulação). A legislação brasileira foi além e adotou um nível mais alto de proteção para o titular, concedendo a exaustão nacional, com vistas a estimular a produção local e a transferência de tecnologia consoante os artigos 7 e 8 do TRIPS -, por entender que o mero depósito da patente no Brasil se, por um lado, é mecanismo de difusão da informação e do conhecimento, por outro, não é suficiente para assegurar a efetiva transferência da tecnologia, que só se verificaria efetivamente mediante a fabricação local do objeto da patente. Se o titular decide não fabricar o produto no país, optando por importá-lo, ele estará desatendendo o interesse do país que lhe concede um título para exploração monopolística do mercado nacional - em seu desenvolvimento tecnológico e o interesse da sociedade no estímulo à inovação. Sendo assim, passa a desmerecer a proteção ampliada, retornando-se à regra geral da exaustão internacional. Não obstante, não haverá prejuízo para o titular da patente, pois o produto importado - por ele mesmo e por terceiros - terá sido produzido e vendido por ele mesmo no mercado internacional. Não há prejuízo para o titular nem violação do TRIPS nessa conversão da exaustão nacional em internacional.

Quando o direito brasileiro estabelece mecanismos de salvaguarda, como a licença compulsória, ele está tentando resgatar a função social do capitalismo, o que é legítimo. A lei de patentes brasileira não é conflitante com - TRIPS, pois os dois instrumentos legais prevêem a existência de mecanismos de salvaguarda, justamente para evitar o abuso do poder econômico. $\mathrm{O}$ direito à propriedade não pode prescindir seu aspecto social e ético.

Nossa conclusão é de que a lei brasileira não fere a legislação internacional. Para chegar a esse entendimento, é preciso avaliar o contexto 
todo e o conjunto de situações envolvidas na disputa. A lei de patentes diz que o dono da patente deve explorá-la mediante produção no território brasileiro. De um modo geral, isso não acontece, e os remédios são importados, muitas vezes com preços altíssimos. E o dono da patente não pode simplesmente se negar a fabricar e a dar licença para produzir no Brasil. Nessa situação concreta e específica, isso pode ser considerado um abuso de direito, o que representa um fundamento jurídico legítimo para que o Brasil possa recorrer aos artigos 68 e 71 da sua lei de patentes, que prevê a licença compulsória em caso de "emergência nacional ou abuso econômico". Nesses casos, o próprio TRIPS, embora não exija a fabricação local, prevê para cada Estado o direito de estabelecer salvaguardas para corrigir o abuso do poder econômico.

Ainda que as multinacionais farmacêuticas decidissem produzir em território brasileiro, o Brasil poderia recorrer à tese do abuso do poder econômico. O abuso do poder econômico pode se caracterizar e concretizar de diversas maneiras, sendo que uma delas diz respeito à fabricação local. Existe também a questão dos preços altos. Em outras situações, a produção local pode ser mais cara. É preciso avaliar todo o contexto para verificar se há abuso do poder econômico ou não.

Segundo nossa interpretação, o TRIPS permite a conclusão de que assiste razão ao Brasil. Não há dúvidas de que uma avaliação mais conservadora poderá se afastar um pouco dessa linha e afirmar, por exemplo, que o TRIPS não prevê a fabricação local. Mesmo que se chegue a essa situação, a sociedade brasileira não vai perder nada, já que os grandes laboratórios nunca produziram aqui, e porque seria uma boa oportunidade de o Brasil estimular a indústria nacional a preencher esse vazio.

\section{DIREITOS DE PROPRIEDADE INTELECTUAL RELATIVOS A BIOTECNOLOGIA EM GENES HUMANOS}

A questão dos direitos de propriedade intelectual em relação à biotecnologia em genes é bastante complexa e divide seus estudiosos em dois 
grupos. O primeiro engloba os que defendem a sua concessão por agirem como forma de proteção e de retorno a todo investimento realizado.

\begin{abstract}
"As empresas de todo o mundo vêm voltando a atenção para a moderna biotecnologia como uma das áreas mais promissoras de criação de novos produtos. Isso muitas vezes realiza-se através dos próprios esforços de pesquisa das empresas, criando pequenas empresas especializadas, colaborando com institutos universitários ou combinando essas possibilidades. Indubitavelmente, para tudo isso, a eficaz proteção das patentes é um requisito preliminar para obter a necessária recompensa de atividades cada vez mais caras e complexas." 23
\end{abstract}

O segundo grupo é composto por aqueles que condenam o patenteamento de genes ao entenderem que a biotecnologia deve basear-se em outros parâmetros. "Cremos que os seres vivos não se encaixam bem nos rígidos esquemas das patentes, criadas fundamentalmente para produtos industriais inanimados"24

Questiona-se se a escassa regulamentação jurídica existente atualmente, feita a partir do modelo TRIPS, é compatível com os valores que informam especificamente a biotecnologia em genes, tendo em vista que se concentra no caráter comercial das pesquisas, tratando o assunto a partir da ótica do direito de propriedade, envolvendo a concessão de patentes, os direitos de exploração da propriedade intelectual (copyrigths), a disponibilização dos materiais, informações e resultados obtidos, o segredo comercial, etc.

Ora, se o trabalho na área de biotecnologia, em termos genéricos, pode ser patenteado quando resulta em invenção, automaticamente surge 0 tema das patentes dos seres vivos objetos de tais ações humanas. A insuficiente abordagem jurídica e a necessária fundamentação ética preocupam ainda mais quando se trata do patenteamento de genes, seja de ser humano seja de qualquer outra forma de vida. As seqüências de DNA, até então, foram objeto de apropriação de seu investigador, por se tratar de

\footnotetext{
${ }^{23}$ GUGERELL, Christian. A proteção legal das descobertas genéticas e a patenteabilidde dos organismos vivos manipulados. O escritório europeu de patentes em Munique. CASABONA. Carlos Maria Romeo (org). Biotecnologia, Direito e Bioética. Perspectivas em Direito Comparado. Belo Horizonte: Del Rey e PUC Minas, 2002. p. 263.

${ }^{24}$ SANTOS, Maria Celeste Cordeiro Leite. O Equilíbrio de um pêndulo. Bioética e a Lei: implicações médico-legais. São Paulo: Ícone Editora, 1998, p. 205.
}

Revista Brasileira de Direito Internacional, Curitiba, v.4, n.4, jul./dez.2006 
produto de um processo tecnológico. Mas há quem defenda a insustentabilidade desse entendimento, tratando-se de mera descoberta de algo já existente na natureza viva.

Em relação à manipulação em genes de animais e vegetais, BURILLO destaca as grandes transformações realizadas através da manipulação de genes e cromossomos e da remoção do núcleo da célula para obtenção de todo tipo de informação genética, permitindo o neoproduto (produção nova), o aloproduto (produção nunca antes obtida na espécie) e também o diagnóstico, prevenção ou tratamento de determinada doença. Inúmeras são as aplicações das técnicas de DNA recombinante em animais e vegetais, tais como identificação da variedade ou raça (o que também acontece em relação ao homem); detectação de genótipos com vantagens produtivas (aumento de produção de leite, determinação do sexo dos embriões, etc.), diagnóstico de enfermidades e rastreamento de agentes patogênicos, em relação a doenças hereditárias ou infecciosas e parasitárias. São os melhoramentos ou, nas palavras do autor, as " novas combinações". Além disso, estão sendo desenvolvidos novos organismos a partir da alteração em partes do DNA, modificando-o ou substituindo por outro, natural ou produzido em laboratório. São as denominadas "verdadeiras transformações"25.

Sobre o tema dos direitos de propriedade intelectual dos trabalhos com animais ou vegetais, as legislações dos países tendem a considerar patenteáveis aqueles organismos transgênicos mas não os organismos naturais, ou partes deles. Tal configuração jurídica não leva em conta os riscos e problemas encontrados em tais manipulações, como o sofrimento causado aos animais e o perigo do esgotamento da biodiversidade, tanto em relação às espécies animais quanto vegetais.

No que diz respeito aos genes humanos, a discussão torna-se ainda mais acirrada. De um lado posicionam-se os que defendem o patenteamento de genes humanos, a partir da idéia do progresso técnico e científico que ele

\footnotetext{
${ }^{25}$ BURILLO, Isaias Zarazaga. Biotecnologia genética Ana agricultura e na pecuária (da produção à la carte As novas normas ético-jurídicas). CASABONA. Carlos Maria Romeo (org). Biotecnologia, Direito e Bioética. Perspectivas em Direito Comparado. Belo Horizonte: Del Rey e PUC Minas, 2002. p. 227-261 passim.
}

Revista Brasileira de Direito Internacional, Curitiba, v.4, n.4, jul./dez.2006 
pode representar. Alegam que tratamentos e medicamentos extremamente importantes para a vida das pessoas só existem porque houve a concessão de patentes de genes humanos. Empresas biotecnológicas são as maiores defensoras dessa tese, afirmando que as patentes geram receitas que, por sua vez, permitem o investimento em novas pesquisas. "Assim como a concessão de patentes de medicamentos normais é moralmente aceita pela sociedade, do mesmo modo devem ser tratados os produtos gênicos e as células que os contêm e sejam úteis na terapia gênica somática."

Por outro lado, doutrinadores questionam o que denominam de visão mercadológica dos defensores das patentes de genes humanos. "O conceito global de direitos humanos é ameaçado, já que não só os seres humanos, como partes de seu corpo, poderão ser exclusiva propriedade dos titulares de patentes. Entre as razões éticas ao não-patenteamento de formas vivas, está o fato de que a vida não é uma mercadoria sobre a qual se possam conceder ou ostentar direitos ou monopólios."26

Existem, ainda, correntes menos radicais. Uns defendem a concessão de patentes sobre genes cujas funções estejam definitivamente conhecidas e cuja utilidade seja identificada. Outros incluem a questão no Direito da Personalidade, sendo uma prerrogativa inerente à pessoa humana e cabendo unicamente a ela decidir por conhecer sua identificação genética ou dividir tal conhecimento com alguém, inclusive seu médico.

A terapia gênica tem sido aceita quando realizada nas células somáticas, para tratar exclusivamente de determinadas doenças genéticas graves, afastando a hipótese para fins industriais ou comerciais. Nesse caso, a patente é concedida, apesar dos riscos relacionados ao desvirtuamento de sua utilização. Já a terapia gênica em células reprodutoras, cujas conseqüências podem atingir as futuras gerações, deve ser analisada com mais cautela. Ainda não existem instrumentos suficientes e seguros para sua realização, de modo que toda promessa de concessão de direitos de propriedade intelectual nessa área deva ser proibida.

${ }^{26}$ SANTOS, Maria Celeste Cordeiro Leite. O Equilíbrio de um pêndulo. Bioética e a Lei:
implicações médico-legais. São Paulo: Ícone Editora, 1998, p. 205. Revista Brasileira de Direito Internacional, Curitiba, v.4, n.4, jul./dez.2006 
O tema mais complexo da questão da biotecnologia é, no entanto, o menos controverso: a clonagem humana. As legislações, em geral, proíbem a clonagem para reprodução humana, afastando qualquer possibilidade de apropriação de seu resultado. No entanto, o assunto está longe de ser pacífico haja vista a insistência de alguns cientistas na sua realização.

Tendo em vista se tratar de mecanismos que podem trazer conseqüências também benéficas para a saúde humana, alguns estudiosos e certas legislações têm admitido a clonagem de embriões humanos para pesquisas médicas, com fins sempre terapêuticos. A idéia é fazer transplantes de clones tecidos ou órgãos desenvolvidos a partir de células da própria pessoa que deles necessita.

A Legislação Brasileira ainda não tem o alcance e profundidade que o tema merece. A Constituição Federal não trata especificamente do tema aqui abordado e, na parte da "Ordem Social", estabelece apenas que "A saúde é direito de todos e dever do Estado, garantido mediante políticas sociais e econômicas que visem à redução do risco de doenças e de outros agravos e ao acesso universal e igualitário às ações e serviços para sua promoção, proteção e recuperação." (art. 196). Há quem veja nesse dispositivo a permissão para realização de terapias genéticas no Brasil ${ }^{27}$, assim como 0 capítulo sobre meio ambiente (art. 225 e seguintes, mencionados na seqüência).

A Lei de Patentes exclui do rol de invenções os seres vivos naturais ou partes deles, inclusive o genoma, mas permite o patenteamento de seres transgênicos, conforme artigo 10, IX e artigo 18, abaixo transcritos:

\footnotetext{
Art. 10 - Não se considera invenção nem modelo de utilidade:

I - descobertas, teorias científicas e métodos matemáticos;

II - concepções puramente abstratas;

III - esquemas, planos, princípios ou métodos comerciais, contábeis, financeiros, educativos, publicitários, de sorteio e de fiscalização;
}

\footnotetext{
27 “É que o Estado brasileiro, os Poderes Públicos, não podem ser omissos diante dos avanços científicos que podem dar lugar à melhoria da situação de saúde, portanto, da condição do direito à vida, mas que, deve assegurar, por força da Constituição Federal, o acesso às terapias genéticas que geram melhoras substanciais no estado de saúde da população brasileira." ALARCÓN, Pietro de Jesús Lora. Patrimônio Genético Humano e sua proteção na Constituição Federal de 1988. São Paulo Editora Método. 2004. p. 288.
}

Revista Brasileira de Direito Internacional, Curitiba, v.4, n.4, jul./dez.2006 
IV - as obras literárias, arquitetônicas, artísticas e científicas ou qualquer criação estética;

V - programas de computador em si;

VI - apresentação de informações;

VII - regras de jogo;

VIII - técnicas e métodos operatórios, bem como métodos terapêuticos ou de diagnóstico, para aplicação no corpo humano ou animal; e

$I X$ - o todo ou parte de seres vivos naturais e materiais biológicos encontrados na natureza, ou ainda que dela isolados, inclusive o genoma ou germoplasma de qualquer ser vivo natural e os processos biológicos naturais.

Art. 18 - Não são patenteáveis:

I - o que for contrário à moral, aos bons costumes e à segurança, à ordem e à saúde

públicas;

II - as substâncias, matérias, misturas, elementos ou produtos de qualquer espécie, bem como a modificação de suas propriedades físico-químicas e os respectivos processos de obtenção ou modificação, quando resultantes de transformação do núcleo atômico; e

III - o todo ou parte dos seres vivos, exceto os microorganismos transgênicos que atendam aos três requisitos de patenteabilidade - novidade, atividade inventiva e aplicação industrial - previstos no art. 8o. e que não sejam mera descoberta.

Parágrafo único - Para os fins desta lei, microorganismos transgênicos são organismos, exceto o todo ou parte de plantas ou de animais, que expressem, mediante intervenção humana direta em sua composição genética, uma característica normalmente não alcançável pela espécie em condições naturais. (grifamos)

\section{A Lei de Biossegurança (Lei 11.105, de 24/03/2005) não trata} especificamente da propriedade intelectual mas cria uma ampla estrutura para a efetivação do artigo 225, parágrafo $1^{\circ}$., incisos II, IV e V da Constituição Federal $^{28}$. Assim, estabelece normas de segurança e mecanismos de fiscalização de atividades que envolvam organismos geneticamente modificados (OGM) e seus derivados, cria o Conselho Nacional de

\footnotetext{
${ }^{28}$ Art. 225 - Todos têm direito ao meio ambiente ecologicamente equilibrado, bem de uso comum do povo e essencial à sadia qualidade de vida, impondo-se ao Poder Público e à coletividade o dever de defendê-lo e preservá-lo para as presentes e futuras gerações.

$\S 1^{\circ}$ - Para assegurar a efetividade desse direito, incumbe ao Poder Público:

I - preservar e restaurar os processos ecológicos essenciais e prover o manejo ecológico das espécies e ecossistemas;

II - preservar a diversidade e a integridade do patrimônio genético do País e fiscalizar as entidades dedicadas à pesquisa e manipulação de material genético;

III - definir, em todas as unidades da Federação, espaços territoriais e seus componentes a serem especialmente protegidos, sendo a alteração e a supressão permitidas somente através de lei, vedada qualquer utilização que comprometa a integridade dos atributos que justifiquem sua proteção;

IV - exigir, na forma da lei, para instalação de obra ou atividade potencialmente causadora de significativa degradação do meio ambiente, estudo prévio de impacto ambiental, a que se dará publicidade;

V - controlar a produção, a comercialização e o emprego de técnicas, métodos e substâncias que comportem risco para a vida, a qualidade de vida e o meio ambiente (...)
} 
Biossegurança (CNBS), reestrutura a Comissão Técnica Nacional de Biossegurança $(\text { CTNBio })^{29}$ e dispõe sobre a Política Nacional de Biossegurança (PNB) de um modo geral. Em outras palavras determina a legalidade das sementes transgênicas, a permissão da pesquisa com célulastronco de embriões humanos, o uso dos embriões estocados há pelo menos três anos e a proibição da clonagem humana. ${ }^{30}$

Em relação ao polêmico assunto da produção e comercialização de organismos geneticamente modificados, ou seja, aqueles produtos acrescidos de um novo gene ou um fragmento de DNA a fim de que produza uma determinada característica (como resistência maior ou alteração de seu valor nutricional), a lei define que a CTNBio deve analisar tecnicamente o pedido para o plantio do transgênicos cabendo a um conselho de ministros, ao final, analisar se deve permitir ou não a comercialização do produto.

Regulamentação posterior por decreto presidencial definiu que a liberação comercial de transgênicos dependeria dos votos favoráveis de dois terços dos 27 membros da CTNBio. O quorum de maioria qualificada dificultou os trabalhos (desde a regulamentação da Lei de Biossegurança, nenhuma variedade geneticamente modificada havia sido autorizada) então o Congresso aprovou uma lei, sancionada pelo Presidente Lula, apesar da resistência do Ministério do Meio Ambiente, reduziu de 18 para 14 o número de votos necessários às autorizações.

A outra polêmica da Lei versa sobre pesquisas científicas com célulastronco, enquanto células neutras que ainda não possuem características que as diferenciem em relação a partes do corpo humano e que podem ser usadas para gerar um outro órgão. A nova legislação permite a pesquisa em células-

\footnotetext{
${ }^{29}$ Os senadores modificaram a proposta da Câmara dos Deputados e o projeto final concedeu mais poderes à Comissão Técnica Nacional de Biossegurança (CTNBio), em detrimento ao Conselho Nacional de Biossegurança (CNBS), um órgão político com influência dos Ministérios da Saúde e Meio Ambiente.

30 Art. 1‥ da Lei 11.105: Esta Lei estabelece normas de segurança e mecanismos de fiscalização sobre a construção, o cultivo, a produção, a manipulação, o transporte, a transferência, a importação, a exportação, o armazenamento, a pesquisa, a comercialização, o consumo, a liberação no meio ambiente e o descarte de organismos geneticamente modificados - OGM e seus derivados, tendo como diretrizes o estímulo ao avanço científico na área de biossegurança e biotecnologia, a proteção à vida e à saúde humana, animal e vegetal, e a observância do princípio da precaução para a proteção do meio ambiente.
}

Revista Brasileira de Direito Internacional, Curitiba, v.4, n.4, jul./dez.2006 
tronco de embriões obtidos por fertilização in vitro e congelados há mais de três anos, desde que haja autorização expressa dos pais.

Até o advento da Lei, no Brasil, as pesquisas no país se limitavam às células do cordão umbilical e da medula óssea, as quais, entretanto, dão origem a alguns tecidos do corpo, somente.

A permissão para a realização de pesquisas com células-tronco embrionárias humanas decorre do artigo $5^{\circ}$ da lei:

\begin{abstract}
Art. 5o É permitida, para fins de pesquisa e terapia, a utilização de célulastronco embrionárias obtidas de embriões humanos produzidos por fertilização in vitro e não utilizados no respectivo procedimento, atendidas as seguintes condições:

I - sejam embriões inviáveis; ou

II - sejam embriões congelados há 3 (três) anos ou mais, na data da publicação desta Lei, ou que, já congelados na data da publicação desta Lei, depois de completarem 3 (três) anos, contados a partir da data de congelamento.

$\S 1$ o Em qualquer caso, é necessário o consentimento dos genitores.

§ 2o Instituições de pesquisa e serviços de saúde que realizem pesquisa ou terapia com células-tronco embrionárias humanas deverão submeter seus projetos à apreciação e aprovação dos respectivos comitês de ética em pesquisa.

§ 3o É vedada a comercialização do material biológico a que se refere este artigo e sua prática implica o crime tipificado no art. 15 da Lei no 9.434 , de 4 de fevereiro de 1997. (Art. 15. Comprar ou vender tecidos, órgãos ou partes do corpo humano: Pena - reclusão, de três a oito anos, e multa, de 200 a 360 dias-multa. Parágrafo único. Incorre na mesma pena quem promove, intermedeia, facilita ou aufere qualquer vantagem com a transação).
\end{abstract}

Ocorre, porém, que essa cláusula está sendo questionada por uma ação do Ministério Público Federal, de iniciativa do ex-procurador-geral Claudio Fonteles, sob a alegação de que a destruição de embriões viola o "direito à vida", assegurado pela Constituição Federal, tendo em vista que os embriões congelados por mais de três anos em clínicas de fertilização podem ser utilizados nas pesquisas mas, caso não o sejam, vão permanecer congelados ou serão descartados. A Constitucionalidade da Lei está sendo analisada pelo Supremo Tribunal Federal.

A necessidade de incorporação dos diversos pontos de vista a cerca da biotecnologia, incluindo a opinião dos países em desenvolvimento, e a urgência da inclusão do aspecto ético nesse debates fez surgir algumas iniciativas importantes, tais como a realização das Conferências Norte-Sul da Unesco, e a 
criação de organismos nos Estados Unidos, tal como o ELSI: Ethical, Legal and Social Issues Program, e a ELSA Ethical, Social and Legal Aspects, do Programa Biomed, da União Européia.

Apesar de alguns avanços, muitas perguntas ainda ficam sem resposta em relação ao tema objeto desse estudo. LEITE SANTOS instiga-nos:

\begin{abstract}
"Na atualidade, o conhecimento das estruturas relativas à genética segue nas mãos de poucos. Não conhecemos o que há de justiça essencial nos contratos e intercâmbios relativos a concessões de patentes. Respeita-se a dignidade humana de todas as pessoas igualmente nos contatos, compromissos e transações econômicas? Que medidas preventivas controlam a possibilidade de que empresas de produtos genéticos ou de investigação genética sejam objeto de aquisição ou tomadas de controle por parte de outras empresas, amistosas ou não, que podem conduzir a monopólios e conglomerados? O que fará a concessão de patentes de genes para favorecer as investigações futuras? A investigação pura seguirá prosperando de modo independente? Quem será o proprietário das mutações de genes patenteados? Quais serão a longo prazo, no âmbito biológico, as conseqüências para a vida familiar e a sociedade? Quais serão os efeitos a nível internacional da concessão de patente de genes? Que concessões ético-morais estão previstas na concessão de patentes resultantes da interação de animais transgênicos e genes humanos?",31
\end{abstract}

De qualquer forma, tanto internacional quanto nacionalmente, toda discussão sobre direitos de propriedade intelectual em relação à biotecnologia em genes humanos deve estar fundamentada no princípio da dignidade humana e na idéia de que todo ser humano é livre, igual e sujeito de sua própria história, não cabendo, portanto, sua instrumentalização, manipulação e comercialização.

\title{
REFERÊNCIAS
}

ALARCÓN, Pietro de Jesús Lora. Patrimônio Genético Humano e sua proteção na Constituição Federal de 1988. São Paulo Editora Método. 2004

BARRAL, WELBER (Org.). O Brasil e a OMC. $2^{\text {a }}$ ed. ver. E at. Curitiba: Juruá, 2002.

CHINEN, Akira. Know-how e propriedade industrial. São Paulo. Editora Oliveira Mendes, 1997.

${ }^{31}$ SANTOS, Maria Celeste Cordeiro Leite. O Equilíbrio de um pêndulo. Bioética e a Lei: implicações médico-legais. São Paulo: Ícone Editora, 1998, p. 210-211.

Revista Brasileira de Direito Internacional, Curitiba, v.4, n.4, jul./dez.2006 
CASABONA. Carlos Maria Romeo (org). Biotecnologia, Direito e Bioética. Perspectivas em Direito Comparado. Belo Horizonte: Del Rey e PUC Minas, 2002.

CARREAU, Dominique e JUILLARD, Patrick. Droit International Économique. 4를. ed. Paris: LGDJ, 1988.

DAL RI JUNIOR, Arno e OLIVEIRA, Odete Maria (Org.). Direito Internacional Econômico em Expansão. Desafios e Dilemas. ljuí: Editora Unijuí, 2003.

DEL NERO, Patrícia Aurélia. Propriedade Intelectual. A Tutela jurídica da biotecnologia. São Paulo: Revista dos Tribunais, 1998.

POMPEU BRASIL FROTA, Maria Stela. Proteção de Patentes de Produtos Farmacêuticos: o Caso Brasileiro. Brasília: FUNAG/IPRI, 1993.

SHIVA, Vandana. Biopirataria: a pilhagem da natureza e do conhecimento. Tradução Laura Cardellini Barbosa de Oliveira. Petrópolis: Vozes, 2001.

SANTOS, Maria Celeste Cordeiro Leite. O Equilíbrio de um pêndulo. Bioética e a Lei: implicações médico-legais. São Paulo: Icone Editora, 1998.

VIDAL, J. W Bautista. O Esfacelamento da Nação. Petrópolis: Vozes, 1994.

VIDAL, J. W Bautista. Monopólio das Patentes. Revista Adusp, maio 1996.

Workshop Políticas de propriedade intelectual, negociação, cooperação e comercialização de tecnologia em universidades e instituições de pesquisa: análise e proposições. Rio de Janeiro: Rede de Tecnologia do Rio de Janeiro, Brasília ABIPTI, 1998.

Sites consultados: www.inpi.gov.br , www.who.int, www.wipo.int

Revista Brasileira de Direito Internacional, Curitiba, v.4, n.4, jul./dez.2006 